BULLETIN OF KYIV NATIONAL UNIVERSITY OF CULTURE AND ARTS

Series in Management of Social and Cultural Activity: Scientific Journal, Volume 2 (2019), Number 2, pp. 100-120

doi: https://doi.org/10.31866/2616-7573.2.2019.190637

ISSN 2616-7573 (Print), ISSN 2617-1104 (Online)
ORIGINAL ARTICLE

(C) L. Batchenko,

L. Honchar, \&

I. Blyzniuk, 2019

UDC: 005.21:338.48

JEL Classification: D12, D22, D41, L25

Received: 30/10/2019

\author{
Liudmila Batchenko $^{1}$, Liliia Honchar ${ }^{2 *}$, \& Iryna Blyzniuk ${ }^{3}$ \\ ${ }^{1}$ Professor, D.Sc., Kyiv National University of Culture and Arts, Kyiv, \\ Ukraine; e-mail: ludavic@ @meta.ua; orcid id: https://orcid.org/0000-0001- \\ 6975-5813 \\ ${ }^{2}$ Senior Lecturer, $\mathrm{PhD}$, Kyiv National University of Culture and Arts, Kyiv, \\ Ukraine; e-mail: glo1991 @ bigmir.net; orcid id: https://orcid.org/0000- \\ 0001-5621-0910 \\ ${ }^{3}$ Manager, LTD “Goodtrip” Kyiv, Ukraine; e-mail: alexandrovna2303@ \\ gmail.com; orcid id: https://orcid.org/0000-0002-9373-3232 \\ * Corresponding author: Liliia Honchar, Kyiv National University \\ of Culture and Arts, 36, Y. Konovalets st., 01601 Kyiv, Ukraine; \\ e-mail: glo1991@ bigmir.net; tel.: +380969836835
}

\title{
Strategic Alternatives Formation for Organizational and Economic Development of Enterprises in Socio-Cultural Sphere
}

\begin{abstract}
Introduction. The relevance of the article is due to the current tendencies of rapid development of business processes and the search for universal and effective strategic mechanisms for more effective functioning of social-cultural sphere. Purpose and methods. The purpose of the article is to carry out a thorough theoretical analysis, systematization and generalization of scientific provisions on strategic management problems in order to find universal strategic solutions for enterprises in the context of tourism. Scientific analysis is carried out by methods of analysis and synthesis, situational, analytical, comparative and statistical. Results. The multifaceted views of scientists on the concept of "strategic alternatives" are considered. The statistical analysis of the dynamics of the development of the tourist services market in Ukraine is carried out. The role of strategic indicators in the activity of enterprises of the social-cultural sphere through the lens of tourism enterprise is investigated. The
\end{abstract}


interdependence of strategic alternatives and strategic goals of enterprises is proved. Conclusions and discussion. Strategic indicators are one of the most important indicators of the activity of enterprises, the results of which most effectively demonstrate the effectiveness of implementing the current strategy or strategic alternatives. The criteria for selecting strategic indicators, which are universal and can be used by enterprises of different types in the social-cultural sphere, have been systematized. The scientific novelty lies in the argumentation of the interdependence of strategic alternatives and strategic goals on the example of the tourism industry enterprise and the modification of the multi criteria approach to the choice of strategic indicators of organizational and economic development of enterprises. The practical importance of the study in bringing in the level of specific methods and recommendations of a flexible, adaptive mechanism for the formation of strategic alternatives and their optimization.

Keywords: social-cultural sphere, tourist market, strategic alternatives, strategic indicators, strategic goals, enterprise, organizational and economic development.

\section{Introduction}

The problem formulation. Modern transformations that take place in Ukraine during a few years caused significant changes and transformation of sociocultural activity of the population of the country. In the modern sociocultural space of Ukraine that develops, basic changes are tested by scienceintellectual, aesthetic and artistic spheres of population activity. Development of cultural and artistic achievements pulls development of international and internal tourism that extends a sociocultural sphere extraordinarily widely also.

In the modern economy, the need for a well-considered and promising approach to the entrepreneurial activity development becomes especially important, since in the domestic economy there is a changing competitive environment, which significantly and constantly increases the requirements for the economic activity of economic units. It is the definition of strategic alternatives of organizational and economic development of tourism enterprises that is one of the most important tasks that must be solved before the implementation of a certain strategy in the enterprise.

The economic development of Ukrainian tourism industry enterprises is not only an instrument for positioning the Ukraine brand far beyond its borders, but also one of the factors of replenishing the country's foreign currency reserves, ensuring employment of the population and increasing the profits of the Ukrainian state (including at the expense of the military and the event tourism), which is due to the fact that the tourism business is one of the main sectors of the service sector, which has been rapidly gaining weight in recent years. However, the difficult economic and political situation, rapid scientific and technological development, the introduction of martial law in a certain territory of the country, the functioning of visa-free travel with se- 
veral countries require the revision of the strategic management vector of the tourist enterprise, not only to ensure its profitability in the face of unforeseen changes, but also for the purpose of ensuring the development of the tourism industry and the economy of the state as a whole.

Today there are a huge variety of definitions of strategic alternatives from different domestic and foreign scientists. Paradoxically, despite the large number, there is still no single definition. Each scientist brings his vision to the definition of this concept.

Some consider the strategic alternative to enterprise activity as a comprehensive program of action, while others say it should be one, but at the same time very clearly and carefully considered and developed a strategy.

Each basic enterprise strategy "gives life" to several strategic alternatives with different features and properties. It is the combination of these alternatives that is the key factor that gives us a wide margin to look for new business management options, but it should be borne in mind that 15 mandatory principles that must be adhered to formulate strategic alternatives.

The analysis of the activities of international global tourism enterprises shows that the basis of their success is the innovative approach to the formation of different strategic alternatives and their obligatory improvement, full review of the portfolio of strategies and rationalization of customer service on the basis of key opportunities and projected profits. These enterprises are developing very quickly due to innovative approaches to solving certain issues of the enterprise activity in order to increase their competitiveness.

The introduction and improvement of strategic alternatives to the functioning of tourism enterprises of various types in this field of activity are a prerequisite for the formation and development of market relations in the tourism sector of the national economy. External activities and the primary improvement of its regulation mechanisms play a particularly important role in solving strategic problems of enterprises.

Alternative action strategies may in the future be the general action programs in the long term with constant improvement of business efficiency, which will ensure the firm's position in the market.

Scientific research is relevant both in scientific and applied aspects and is conditioned by the needs of modern business practices that are in search of a new business model, based on the humanistic approach of today.

State study of the problem. The process of strategic management and the formation of strategic alternatives are devoted to the scientific works of foreign and domestic scientists: I. Ansoff (1972), O. Bartoshuk (2012), M. Weber (1947), F. Herzberg (1968), A. Kruhlianko (2012), V. Kucherenko (2010), H. Mintzberg (1994), M. Porter (1985), R. Robinson (Pearce \& Robinson, 1991), 

A. Thompson and A. Strickland (2006), D. Schendel (Schendel \& Hatten, 1972), O. Shershnova (2004) and else.

Some aspects of social and economic development of business models of social-cultural enterprises were considered in the works of P. Kerzhentcev (1921), R. Likert (1932), A. Maslow (1943), E. Mayo (1946), P. Sorokin (2005) and else.

Studies on various aspects of tourism industry development are also contained in the works of L. Ahafonova and O. Ahafonova (2002), R. Braymer (2005), M. Malska, H. Antoniuk and N. Hanych (2008), T. Tkachenko (2006) and else.

Thus, in the scientific literature, there is no single definition of the concept of strategic alternatives to enterprise development. For example, O. Kovtun (2008) determines that strategic development alternatives should be understood as pre-projected, quantified development scenarios, and developed for each of these options by the system of actions (strategies) to be implemented or adhered to by the enterprise in order to achieve its strategic goals of securing the future profitability in the industry in which it operates. The main purpose of this process of forming a certain strategy, the author calls directly the choice of strategic alternative, which will be able to improve the efficiency of the enterprise and profitability in the future (p. 209).

M. Khatser (2014) considers an alternative strategy for enterprise development as a general and necessarily complex program of actions, expressed in both quantitative and qualitative forms. It is they who can give a clear idea of the possible future conditions and parameters of the dynamics of development of economic entities, with further consideration of their own goals and resources that are necessary to achieve them (p. 110).

O. Tur (2015) notes that strategic organizational and functional strategies are a strategic alternatives to enterprise development (pp. 44-45).

S. Horbachenko and K. Moiseienko (2016) argue that the choice of strategic alternative consists in the choice of such a strategy of enterprise development that will provide more efficient use of material resources of the enterprise, optimization of long-term rate of profit, strengthening of competitive positions of the enterprise, maximizing capital investment and customer satisfaction (p. 35).

At the same time, the process of forming the chosen strategy, according to the authors, is complicated and consists in the fact that, apart from the various theoretical and methodological approaches, this process is considered from a specific standpoint, namely, the formation of the strategy as: a process of reflection; formal process; analytical process; the production process; mental process; an evolving process; collective process; jet process; process of transformation. 
I. Tuchkovska and V. Yashchuk (2017) point out that the principle of alternative competitiveness of enterprises operating in the tourism industry should underpin the formation of strategic alternatives (p. 220).

$O$. Bartoshuk (2012) notes that the strategy for the development of enterprises in the tourism industry should be carried out on the principles of optimality, scientific validity, complexity, objectivity, dynamism, adaptability, dimension, systematic, logical, specific, adequate, transparent, legitimate, active and controlling (pp. 38-41).

A. Kruhlianko (2012) notes that it would be imperative to use M. Porter's approach, which takes into account the characteristics of a particular tourist region and the relevant market. The presence, diversity and level of development of attractive tourist sites, market infrastructure, and the effectiveness of strategic management of the tourism enterprises themselves should be included. Uniformity of tourist regions is reflected in the mechanism of formation of growth strategies of enterprises in the tourism industry. The author also emphasizes that the life cycle of the business sphere is a particularly important factor that should be considered when choosing a strategic alternative for the development of a tourism enterprise or the enterprise strategy itself. Each business area is typically characterized by a particular type of growth and growth strategy. According to the author, the main focus of management attention on the above points will give real opportunities for potential strategic development of the tourism enterprise, increasing the efficiency of its management and at the same time considerable savings of limited financial resources (p. 66).

V. Kucherenko (2010) emphasizes the use of such an approach as globalization, in the process of forming and implementing a strategy for the development of an enterprise in the tourism industry, the essence of which is to develop such a development strategy, the main provisions of which should be transformed, deepened and adjusted to further lower levels of tourism industry management - region, destination, business (p. 204).

In addition, the multifaceted process of forming and implementing an alternative strategy for the development of the tourism enterprise in Ukraine has recently used an internationalization approach, which presupposes the orientation of the strategic actions of the enterprise to enter foreign markets. The expediency of choosing a strategic alternative according to this approach depends on the level of risk and protectionism of the foreign tourist market, the expected profit of the tourist enterprise, etc. (Orlova, 2015, p. 46).

Strategic development alternatives should not include a system of oneoff measures, but should ensure that there are sound, consistent, complex enterprise development measures aimed at achieving the overall strategic goal of enterprises over the long term. 
In the context of the foregoing, it is pertinent to mention the famous classicist John Keynes (1937), who, at the beginning of the twentieth century, emphasized that culture and tourism must be international, considering the content of national self-sufficiency.

Thus, it can be concluded that the question of formation of strategic alternatives of organizational and economic development of enterprises of social-cultural sphere through the lens of development of the tourist industry of Ukraine remains insufficiently researched, taking into account international trends and world practices with their adaptation to national strategic tendencies of economic development and accordingly relevant for further research.

Unresolved issues. Despite the rather wide volume of publications on these problems, the issues of forming strategic alternatives to the activity of enterprises, taking into account the social-cultural approach, remain quite complex and ambiguous. In today's context, the specifics of the strategic development of social-cultural sphere in general and the solution of problems of alternative strategic development of the enterprises of the branches are possible and urgently needed.

The development, implementation and improvement of unique strategic alternatives to the development and functioning of social-cultural enterprises in the context of the development of the tourist industry of Ukraine are a priority task that requires constant adequate and flexible management decision in accordance with sectoral, national and global changes in the external environment, which has a real impact on the environment, formation and development of market relations in the tourism sector of the national economy.

Additional research in the context of the tourism industry is subject to the definition of modern international strategic indicators, optimization on their basis of the strategic goals of the enterprises, which are now fully identified with the strategic alternatives for the development of enterprises of the social-cultural sphere.

\section{Purpose and research methods}

The purpose of the article is to analyze and substantiate the choice of strategic alternatives to the complex organizational and economic development of social-cultural enterprises in the context of the development of the tourism industry of Ukraine, as a significant component of it; summarize the principles for selecting strategic alternatives, depending on the strategy being implemented.

The methodological basis of the study was a complex of interrelated set of theoretical, methodological and applied aspects. These are the works of domestic and foreign scientists in the field of strategic management and 
social-cultural activity; methods, methods and means of cognition of theory; concepts, economic laws and laws; principles and approaches to problem research, as well as a number of theoretical, empirical and practical methods. The main task of the methodology is the process of knowing the system of principles, methods, rules and norms, which have already been tested over time and have been tested both in foreign and domestic business models.

Based on methodological principles (unity, theory and practice, historical approach to the study of the problem, objectivity, comprehensiveness (comprehensive approach), systematic), methodological requirements for carrying out scientific research on the optimization of strategic alternatives of organizational and economic development of social-cultural enterprises were formulated. These are: critical research and analysis of strategic alternatives formation processes; flexibility and adaptability to innovations in the theory and practice of social and cultural management; strengthening in the scientific research of the practical orientation, the importance of the developed recommendations on the economic development of enterprises of social-cultural sphere; ensuring the validity of scientific forecasting, vision of prospects for the development of enterprises of social-cultural activity, in particular the tourism industry; upholding the logic of judgment and purity in the theoretical, analytical and advisory aspects of scientific research.

Summarizing these requirements for research results can be briefly defined as objectivity, reliability, reliability, and evidence. Thus, the methodology in the broad sense is a rational mental analysis of scientific thought, it is rational action using the methods that must be envisaged to solve the tasks and achieve the goals of the study.

Research methods. The study reflected a wide range of scientific research methods, both general scientific and specialized and practical.

The methods of analysis, synthesis, generalization, abstraction, concretization, analogy, formalization, explanations, terminological analysis, system analysis, classification, structuring - in theoretical analysis of scientific sources, approaches of different authors to understanding the processes of formation of strategic alternatives of enterprise development spheres; to a systemic vision of an adaptive effective mechanism of organizational and economic development; to take into account modern trends and features of development of enterprises of social-cultural sphere.

From the special methods, the methods of economic analysis, functional, dynamic, economic and mathematical modeling, method of financial coefficients, scenario forecasting method were applied - in assessing the existing indicators of the activity of enterprises, their share and place in the market environment and determining strategic indicators of further development using sub criteria approach. 
Practical methods used methods of observation, comparison, modeling to justify the interdependence of strategic alternatives with the strategic goals of enterprises of social-cultural sphere.

Also, the methods of related sciences, in particular management, sociology, psychology, economics, statistics, were used in the scientific research.

Research information base researches consisted of works of domestic and foreign scientists, including works of the teaching staff of KNUKiM, materials of state statistical bodies of Ukraine, Laws of Ukraine, legislative and regulatory acts, expert assessments, financial statements of branch enterprises, materials of scientific periodicals, official resources of the Internet, as well as the results of own research done while writing this work and practice materials.

\section{Research results}

The main consumers of tourist services in Ukraine are Ukraine's own population and foreigners who have visited Ukraine. According to the statistics of the Administration of the State Border Guard Service of Ukraine, in the first half of the year there is a decrease in inbound tourism in the first half of 2018, as opposed to the same indicator for the last year and an increase in outbound tourism in the first half of 2015-2018 (Figure 1).

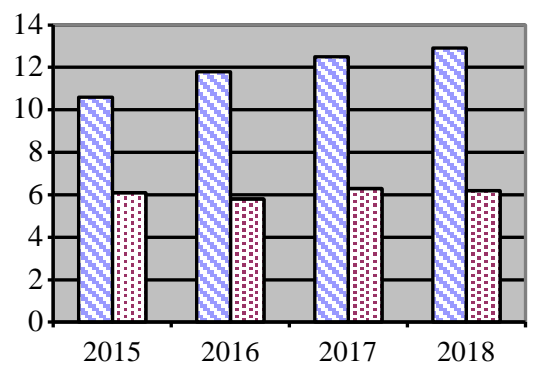

QUkrainians, who went abroad Foreigners, who entered Ukraine

Figure 1. Arrival of foreigners to Ukraine and departure of Ukrainians abroad for the first half of 2015-2018

Source: development on the basis of (Ministry of Economic Development and Trade in Ukraine, 2018)
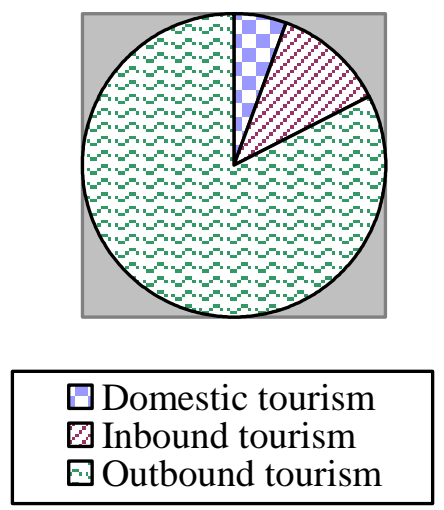

Figure 2. The share of tourism by volume of tours sold by tour operators

Source: development on the basis of (Ministry of Economic Development and Trade in Ukraine, 2017) 
Speaking about the quantitative characteristic of inbound tourism, in the 1st quarter of 2018 foreigners came in $3.1 \%$ less than in the corresponding period last year. In the 3 rd quarter the share of the number of foreign tourists is about $33 \%$ of the total number of foreign tourists who went during the year, which is explained by the summer season and the period of holidays in the 1st quarter - 17-18\%. Overall, during the analyzed years there is a steady increase in inbound tourism during the second half of the year: yes, 6.81 million people visited Ukraine in 2015, 7.79 million and 8.09 million respectively in 2016 and 2017.

Analyzing the data from the tour operators presented in Figure 2, it can be noted that in 2017 the largest share also came from outbound tourism.

During the specified period, tourists made trips in order to:

1) cultural and cognitive -1533.9 thousand of people;

2) with the official - 106.9 thousand of people;

3) with health-improving - 22.1 thousand of people;

4) event tourism -7.3 thousand of people;

5) cruise line -3.1 thousand of people;

6) mountain tourism - 2.6 thousand of people;

7) adventure -2.0 thousand of people;

8) sports -1.8 thousand of people;

9) others -884.5 thousand of people.

These indicators are influenced without exception by all tourist enterprises that are currently operating. By defining ways and methods of development for themselves, they thus contribute to the total volume of client flows in Ukraine and the world at large.

The effectiveness of the formation and implementation of a comprehensive strategic alternative to the development of any enterprise is determined by the adequacy and compliance of the program objectives of the company. Strategy development and business alternatives will greatly coincide with the development indicators of the facility itself. Its complex and systematic development is precisely the purpose for which this program is being implemented. The indicators identified by the company are step-by-step evaluation and analysis of the progress of implementation and implementation of the program, determine the level of achieving results - they meet expectations or vice versa. Therefore, it is always a very important task to select accurate and correct business development indicators, from the vast array of different statistics available in the facility management department. Different types of indicators are always used.

Strategic indicators are the key indicators in the activity of tourism enterprises that the enterprise is focused on for successful operation. Depen- 
ding on the main strategic goal, they are different for each enterprise. Types of strategic indicators and their content are presented in Figure 3.

\begin{tabular}{|c|c|c|c|}
\hline \multicolumn{4}{|c|}{ Indicators } \\
\hline Direct & Indirect & Ouantitative & Oualitv \\
\hline$\frac{1}{t}$ & $t$ & $\downarrow$ & $t$ \\
\hline $\begin{array}{l}\text { On the own } \\
\text { initiative of the } \\
\text { enterprise and } \\
\text { other } \\
\text { stakeholders; } \\
\text { spot analysis } \\
\text { to track the } \\
\text { performance } \\
\text { of key success } \\
\text { indicators }\end{array}$ & $\begin{array}{l}\text { According to the } \\
\text { monitoring analysis } \\
\text { of problem areas. } \\
\text { Applied after } \\
\text { management } \\
\text { decision on the } \\
\text { economic need for } \\
\text { the cost of evaluating } \\
\text { non-strategic } \\
\text { indicators }\end{array}$ & $\begin{array}{l}\text { Indicators that } \\
\text { have a } \\
\text { quantitative } \\
\text { value and are } \\
\text { manifested } \\
\text { by number, } \\
\text { frequency, } \\
\text { percentage, } \\
\text { proportion, } \\
\text { etc. }\end{array}$ & $\begin{array}{l}\text { Indicators that have } \\
\text { qualitative value } \\
\text { and are explained } \\
\text { by the following } \\
\text { formulations: } \\
\text { availability, } \\
\text { relevance, quality, } \\
\text { degree, level, } \\
\text { satisfaction, } \\
\text { awareness, } \\
\text { etc. }\end{array}$ \\
\hline
\end{tabular}

Figure 3. Classification of strategic indicators

Source: development on the basis of (Halitsyn, Suslov, \& Samchenko, 2013)

Quantitative indicators can always describe the frequency and number, the growth rate of the economy, which is always reflected in quantitative value, indicators of macroeconomics and microeconomics, price levels, tariffs and more.

Depending on the need, quality indicators can describe the attitude of stakeholders and consumers to a particular product or service, their level of satisfaction or vice versa, willingness to make a decision, self-esteem, change in behavior, etc.

In practice, it is desirable to maintain a balance between quantitative and qualitative indicators. Sometimes it is possible to determine qualitative indicators through the use of quantitative indicators, which in sum can give an overall qualitative and complete picture.

The reference point in the analysis of the activity of the enterprise is the definition of intermediate and final indicators. They serve to define and position the control points. Intermediate indicators are set to determine the outcome at specific times or stages of strategy implementation. Therefore, they actually serve as benchmarks to achieve the expected end results. Indicators of the outcome of a strategy are inherently summarized. The criteria for selecting indicators are presented in Table 1. 
The mission of modern tourism enterprises is to provide quality service for tourists of different income, age group, nationality, social category, preferences. The strategic goal of enterprises is to maximize profits by effectively meeting the needs of the tourism market in innovative service.

Table 1. Polycriteria of indicators

\begin{tabular}{|l|l|}
\hline \multicolumn{1}{|c|}{$\begin{array}{c}\text { Selection } \\
\text { criteria for } \\
\text { indicators }\end{array}$} & \multicolumn{1}{c|}{ Characteristics and content of the criterion } \\
\hline Conformity & $\begin{array}{l}\text { Measuring the progress of implementation and implementation } \\
\text { of both the holistic strategy and its individual steps }\end{array}$ \\
\hline Sensitivity & Response of the indicator to any changes \\
\hline Accessibility & Openness and ease of information collection and handling \\
\hline Reliability & Reliability and consistency of data for indicators over time \\
\hline Simplicity & The level of complexity of measuring indicator data \\
\hline Objectivity & $\begin{array}{l}\text { Ability to simultaneously and identically understand data } \\
\text { between all participants }\end{array}$ \\
\hline Frugality & $\begin{array}{l}\text { Will the costs of obtaining information be comparable to } \\
\text { the benefits of monitoring? }\end{array}$ \\
\hline Representation & $\begin{array}{l}\text { The ability to identify a specific age group or class of } \\
\text { customers or participants in an organizational process }\end{array}$ \\
\hline
\end{tabular}

Source: own development on the basis of (Ministry of Economic Development and Trade in Ukraine, 2019; Wynnycky, Lendel, Ratajczak, \& Sanzharovskyi, 2007)

On the basis of this aim, the enterprises of the tourism industry today have strategic development alternatives that are completely in line with the strategic goals presented in Figure 4.

Depending on the specific gravity of the differentiated product, enterprises are developing active or passive measures to optimally support such tourism products in order to build customer loyalty, paying close attention to such indicators as:

- prompt work on the selection and organization of the tour at the request of the client;

- courtesy of service, attention to the requests of each client;

- patience when discussing the route, etc.;

- the relevance of the proposed tour to the actual content; 
- coordination of all components of complex service;

- route selection time;

- time of registration of necessary documents;

- time to get help information, etc.

In addition, it is precisely in the areas of differentiation that companies develop a portfolio of services that differ in their class of services, prices, which allows a potential buyer to choose the most interesting and affordable option.

\begin{tabular}{|c|c|}
\hline \multicolumn{2}{|c|}{ Modern strategic goals of tourism industry enterprises } \\
\hline & Increase in the number of counterparties \\
\hline & Coverage of new destinations in tourism \\
\hline & $\begin{array}{l}\text { Development and implementation of new solutions in our own } \\
\text { system of search and reservation of public systems }\end{array}$ \\
\hline & Increasing the number of partners \\
\hline & Profit maximization \\
\hline & Functional filling of the portfolio of travel packages \\
\hline & Loyalty programs \\
\hline & Information and advertising support for marketing activities \\
\hline & Brand of the enterprise in the tourist market \\
\hline
\end{tabular}

Figure 4. Modern strategic goals of tourism industry enterprises

Source: development on the basis of (Zorin, Kaverina, \& Kvartalnov, 2001, p. 178; Tkachenko, 2006, p. 482)

At the present stage, the following strategic goals play a leading role in the selection of strategic alternatives to the activity of tourism industry enterprises:

- increasing the number of contractors and partners;

- coverage of new destinations in tourism;

- functional filling of the portfolio of travel packages;

- development and implementation of new solutions in the activity of the enterprise;

- information and advertising base of marketing activity;

- professional competence and quality of service of tourists;

- profit maximization. 
In order to enhance the soundness of the study of the value and role of certain strategic indicators in the organizational and economic development of domestic tourism enterprises, it is advisable to carry out a practical-oriented analysis of their provision on the example of an existing tourism enterprise. The features of targeting each strategic indicator and ensuring its effectiveness should be considered through the lens of the tourism enterprise LLC "GOODTRIP", which for 4 years conducts its activity, based on the concepts of increasing the number of contractors and partners, information and advertising support for marketing activities of the enterprise, functional filling the portfolio of travel packages, maximizing profits - while gaining a separate niche in the tourist services market of Ukraine.

In the direction of increasing the number of counterparties for partners, LLC "GOODTRIP" has a very active policy and at the moment has agency agreements with such leading tour operators as LLC "Join UP!", LLC "TEZ TOUR", LLC "Travel company Annex tour", LLC "Delta Travel”, LLC "Pan-Ukraine", LLC "Zeus Travel”, LLC "Coral Travel”, LLC "COMPASS UKRAINE”, LLC "TTVK” (tm TUI Ukraine), LLC "Alpha Tour Operator", LLC "OASIS", LLC “Accord Tour”, LLC "MUZENIDIS”, PE "Lyubosvit", LLC "Travel Professional Group", LLC "NORDIC Travel”, LLC "Aristea Tour", LLC "Ukrainian Tourist Center", LLC "Pilon Ukraine”, PE "Olymp", LLC "Siesta", LLC "Tourist Club", LLC "HKS", LLC "Global Global Company".

The companies' remuneration for each of the contracts is from 1 to $12 \%$ of the cost of the tour or service, which was realized using the electronic reservation system or under agency agreements with travel agents.

The company also has many related agreements with the leading airports of Ukraine for servicing VIP clients, with companies servicing telephone, Internet and online banking through which merchants of payment systems of banks are established for receiving online payments from clients.

In order to provide a functional filling of the portfolio of travel packages, LLC "GOODTRIP" cooperates with five leaders in the tourist market of Ukraine. The company is fully trying to deliver to its customers the services they offer in their fulfillment.

Considering the top five among tour operators in the Ukrainian market of tourist services, it is worth noting that LLC "Join UP!" Is a multidisciplinary tour operator, adheres to the product differentiation strategy and offers travel services in 40 destinations. It also has a network of 115 travel agencies in 48 cities in Ukraine. In addition, LLC "Join UP!" is one of the largest customers of charter flights. The company has a strategic integration partner Skyap Airlines LLC, which is a low cost carrier. All charter flights from this tour operator and the new Ukrainian Airlines are available for passengers to book through LLC "GOODTRIP”. 
“Anex Tours Travel" Company offers more than 30 destinations to clients. Has strategic integration partners:

1) LLC "Azur Air Ukraine" is a Ukrainian air carrier,

2) AstlasGlobal is a Turkish air carrier;

3) PuAT IC "VUSO" is a travel insurer.

Azur Air Ukraine charter flights are unique, as their purchase was only possible as part of travel packages. The purchase of charter flights in some of the destinations is now possible through LLC "GOODTRIP", which has links with the cooperation with this tour operator.

LLC "Travel Professional Group" adheres to a product differentiation strategy by offering travelers a 20 -way travel service. In addition, it employs an integration strategy, having cooperative agreements with more than 40 tour operators worldwide, as well as leading airlines, including: Air France, Lufthansa, Austrian Airlines, SAS, Baltic Airlines, KLM, MAU, Windrose, Fly Dubai and others.

LLC "TEZ TOUR" offers travelers a tourist product in more than 45 destinations. The tour operator has strategic partners for integration:

1) partner carriers, including: UIA, I Fly, Thai Airways, Emirates, QATAR AIRWAYS, Air Baltic, Air Arabia and others;

2) hotel partners, incl. brands Marriott, Sheraton, Le Meridien, Sol Melia, Princess, Hilton, Iberostar, Four Seasons and more.

LLC "Coral Travel" belongs to the international structure of OTI Holding, which also owns companies. Coral Travel LLC offers clients more than 28 destinations. Has horizontal integration partners: Odeon Tours, A-Class Travel, Holiday Market Service, Otium Hotels, Xanadu Resort Hotel, OGD Security \& Consultancy (all owned by OTI Holding). The tour operator has its own base of charter programs and scheduled flights.

All charter programs of each tour operator are unique and unique, and all of them are simultaneously available for selection and booking at LLC "GOODTRIP". It is due to the diversity of the portfolio of tourist packages that the company differentiates its services. One example of the differentiation and dynamics of sales of travel packages is presented in Table 2.

Such differentiation of tourist services is based on such factors of differentiation as: quality of service of tourists; flexibility of pricing policy; the functional filling of the tourist package; professional competencies of managers of the reservation and sales department; customer relationship in customer base format; availability of loyalty programs; information and advertising support for marketing activities; the brand of the enterprise in the tourist market.

At present, information and advertising support for the sales activity of the enterprise LLC "GOODTRIP" is under development. At present, the company does not clearly have its own product, but is engaged in the sale of the 
product of leading tour operators. Thus, information and advertising support are provided by supporting entire networks of leading tour operators.

Thus, the LLC "Coral Travel Travel" Agency network has 300 offices in 55 cities of Ukraine. The LLC "TUI" travel agency network has 250 offices (the tour operator and franchises themselves). They cooperate not only with the tour operator, but also with the UIA carriers and the Wind Rose, as well as with the travel insurer of PuAT "European Travel Insurance".

Table 2. The share of tourist destinations in the total volume of services provided by country

\begin{tabular}{|l|c|}
\hline \multicolumn{1}{|c|}{ The direction of differentiation } & Proportion, \% \\
\hline Egypt and Turkey & 38 \\
\hline Greece and Bulgaria & 27 \\
\hline Charter flights in the rest of the destinations & 25 \\
\hline Exotic countries (Asian countries and island republics) & 8 \\
\hline UAE & 2 \\
\hline Total & 100 \\
\hline
\end{tabular}

Source: development on the basis of (Goodtrip, 2018)

The network of travel agencies LLC “Join UP!" Has 127 offices - representative offices, including: 21 - actually tour operator, 106 - franchise. The peculiarity of the network is a strong tour operator advertising company, which also includes cooperation with popular TV shows (Eagle and Reschka and others), which greatly facilitates the work of agents in search of new clients.

Developing and implementing new solutions in the implementation of its activities, LLC "GOODTRIP" also uses the features of the leading tour operators together with their unique solutions when selling their goods and services.

In particular, the LLC "Coral Travel" network's peculiarity is that in the tourist services market, they are represented by two types: LLC "Coral Travel" Agency and LLC "Coral Elite Service Travel" Agency, the latter of which are designed for high-income clients. For special services not provided by regular agencies, LLC "Coral Elite Service Travel” offers a special tour organization to a country that is not included in the list of destinations of tourist products that are usually provided by the company, and also provides the opportunity to call a personal travel manager for the office or home. Undoubtedly, Coral Elite Service's client base is completely confidential, and persons working in agencies sign agreements on non-disclosure of information that they have become aware of in the course of their professional activity. In other words, the product is differentiated not only by the tour operator, but also by the agencies with which it cooperates. 
In terms of professional competences and quality of tourist services, all booking managers at LLC "GOODTRIP" are professionally equipped enough to work with clients. Agents must know the client's travel history. This helps to give the consultation much better and better: the agent will be able to pick the right hotel tourist for all parameters and not repeat the previous mistakes. The main tasks of the agent are the competent support of the tourist at all stages: check of all documents, control of departure, support with emergency situations, a service of the client during rest and after his return.

Profit maximization at the enterprise of LLC "GOODTRIP" is carried out with the help of horizontal diversification strategy by dividing such types of business, such as:

1) providing a possible advertising platform for tour operators based on an electronic search and booking system (including branding of tour operators, branding of tour operator products, etc.);

2) implementation of agency activities (acting as an authorized travel agent);

3) booking of tickets;

4) use of travel agents by the search and booking system.

The share of income of each business unit of the enterprise in total sales is presented in Table 3 .

Table 3. Share of income of business units in total net revenue from the sale of services in 2017-2018

\begin{tabular}{|l|c|c|c|c|}
\hline \multirow{2}{*}{ Type of business unit } & \multicolumn{2}{|c|}{ Proportion, thousand, UAH } & \multicolumn{2}{c|}{ Proportion, \% } \\
\cline { 2 - 5 } & 2017 & 2018 & 2017 & 2018 \\
\hline Corporate service & 9.37 & 40.57 & 23.45 & 5.8 \\
\hline $\begin{array}{l}\text { Travel agency } \\
\text { activities }\end{array}$ & 13.05 & 296.39 & 32.66 & 42.34 \\
\hline Booking tickets & 17.525 & 363.04 & 43.87 & 51.86 \\
\hline Total & 39.947 & 700 & 100 & 100 \\
\hline
\end{tabular}

Source: development on the basis of (Goodtrip, 2018)

Analyzing the data, we can say that the enterprise has a tendency for a constant growth of business units. Thus, the share of revenue from the provision of air ticket services in 2018 is UAH 363.04 thousand compared to 2017 (UAH 17.525), which is UAH 345.515 thousand more.

Income from such business units as a tour agency activity also tends to increase: the share of revenue from the travel agency activity in 2018 amounts to UAH 296.39 thousand, compared to the same indicators of 2017 - UAH 13.05 thousand. The share of the same income from advertising in 2018 compared to 2017 increased by UAH 31.2 thousand. 
The ever-increasing share of revenues from the operation of these business units is explained by the increased cost of these services and the fact that these business units are at the stage of growth of their life cycle.

It should be said that the users of the public electronic search and reservation system and similar systems currently have about 4.500 travel agents and 33 tour operators, and every year the number of those wishing to make money in the tourist market is growing, which means that the tendency to increase the income from these business units in the coming years 5-10 will continue (given the tendency to increase the capacity of the tourism market of Ukraine). However, LLC "GOODTRIP" develops and implements its own electronic search and booking system for airline tickets and travel packages, so revenues from the above mentioned business units will only grow at the expense of product uniqueness.

Considering the above, it can be concluded that LLC "GOODTRIP" is operating successfully and quickly due to the differentiation and diversification of services, as well as through the uniqueness of the services provided. It has strategic ties to the top five, and sells on their behalf, officially being their top-ranked agent.

Implementation of the vital strategies and functioning of the basic strategies will not bring the desired result of the activity, because strategic alternatives are the "keys" in the activity of tourist enterprises, which the whole management of enterprise management of the present and future relies on and focuses on. Today the tourist market is massively transformed, so each segment of the operation needs its unique advantages. Because strategic development and business alternatives are the same as indicators of the development of the entity itself, which must be clearly identified before identifying alternatives.

\section{Conclusions and discussion}

The results of the study on the peculiarities of the formation of strategic alternatives of enterprises of social-cultural sphere through the prism of development of the tourist industry of Ukraine allow us to reach the following conclusions:

1. Today, one of the most important social-cultural phenomena of modern society is tourism. It forms one of the bases of sources of replenishment of the national budget of our country, and also directly and indirectly influences the life activity of the population of the country.

2. Today the tourist market is massively transformed, and therefore each segment of the operation needs its unique advantages. Because strategic development and business alternatives are the same as indicators of the development of the entity itself, which must be clearly identified before identifying alternatives. 
3. Dynamics of analysis of statistics of the tourist services market of Ukraine shows that there is a decline in inbound tourism and an increase in outbound tourism, which threatens the decline of this industry in the future for our country. Almost a large part of the tourist services market in Ukraine is held by five leaders: LLC "Join UP!", LLC “TEZ TOUR”, LLC "Travel Professional Group", LLC “Anex Tour", LLC "Coral Travel” have brought their own strategies of activity to the unique and sell their services in different areas of differentiated services.

4. The analysis of strategic indicators is carried out through the lens of the activity of the enterprise development of GUDTRIP LLC. This company is quite successful at the expense of differentiation and diversification of own provided services. The main strategic indicators of the company management include an increase in the number of contractors and coverage of new areas.

5. It has been argued that implementation of basic strategies will not bring the desired result of activity, because strategic alternatives are the "keys" in the activity of tourist enterprises, which are based and oriented all management of enterprise management of the present and future.

The scientific novelty of the results obtained is as follows:

- justified the choice of strategic indicators in the activity of enterprises of social-cultural sphere of Ukraine through the lens of the tourism sphere during the analysis of the activity of enterprises is substantiated;

- justified the interdependence of strategic alternatives with the strategic goals of tourism enterprises in modern times is argued;

- proved the importance of analyzing indicators of strategic indicators has been proved in order to further identify alternative strategic actions in order to increase the competitiveness of the enterprise and its economic stability.

The practical significance of the results obtained is that the theoretical study of the provisions are brought to the level of specific methods and recommendations, in particular:

- the criteria for selecting strategic indicators in the organizational and economic analysis of the activities of social-cultural enterprises are universal and may serve as a basis for selecting strategic alternatives for enterprises of different specialization;

- are given a variety of strategic goals of business activity are presented through the lens of the tourism industry, which are now completely in line with the strategic alternatives for the development of enterprises in this area and can be used in further strategic planning.

Prospects for further scientific exploration in this direction due to the fact that these theoretical studies and practical recommendations will require further theoretical and methodological and practical developments on the ana- 
lysis, control and adjustment of the proposed alternative strategic actions for the further successful and competitive activity of enterprises in the sociocultural, social and cultural sphere unstable, volatile and acutely dynamic environment.

\section{Acknowledgement}

This publication has been made in accordance with the subject of scientific research of the Department of Hotel and Restaurant and Tourism Business of the Kiev National University of Culture and Arts within the theme: "Formation of reputation of organizations as the main indicator of competitiveness" (state registration number 0115U006582), as well as materials of their own scientific and practical research in the preparation of specialists within the specialty 028 "Management of social-cultural activities" (specialization "Management of hotel, restaurant and tourist business").

\section{References:}

Ahafonova, L. H., \& Ahafonova, O. Ye. (2002). Turyzm, hotel'nyj ta restorannyj biznes [Tourism, hotel and restaurant business]. Kyiv: Znannia (in Ukr.).

Ansoff, H. I. (1972). The Concept of Strategic Management. Journal of Business Policy, 2(4), 2-7.

Bartoshuk, O. V. (2012). Kontseptualni pidkhody do formuvannia stratehii rozvytku turystychnoi haluzi [Conceptual approaches to development of tourism industry development strategy]. Ekonomichnyj chasopys - XXI, Seriia: Ekonomika ta upravlinnia natsionalnym hospodarstvom [Economic Journal - XXI, Series: Economics and Management of the National Economy], 3-4, 38-41 (in Ukr.).

Braymer, R. A. (2005). Osnovy upravleniia v industrii gostepriimstva [The basics of management in the hospitality industry] (E.B. Tcyganov, Trans. in Engl.). Moscow: Aspekt Press (in Russ.).

Gudtrip (2018). Vnutrishni materialy pidpryiemstva TOV “Gudtrip" [Internal materials of the enterprise LTD "Gudtrip"] (in Ukr.).

Halitsyn, V. K., Suslov, O. P., \& Samchenko, N. K. (2013). Systemy monitorynhu [Monitoring systems]. Retrieved from https://regulation.gov.ua/arvmaterials/indicators (in Ukr.).

Herzberg, F. (1968). "One More Time: How Do You Motivate Employees?" Harvard Business Review, 81(1), 87-96.

Horbachenko, S., \& Moiseienko, K. (2016). Stratehiia rozvytku pidpryiemstva: poniattia ta sutnist' [Enterprise development strategy: concept and essence]. Naukovyj visnyk Odes'koho natsional'noho ekonomichnoho universytetu [Scientific Bulletin of the Odessa National Economic University], 10, 31-44 (in Ukr.).

Kerzhentcev, P. M. (1921). Printcipy organizatcii [The principles of organization]. Moscow: Gosudarstvennoye izdatelstvo (in Russ.).

Keynes, J. M. (1937). The General Theory of Employment. The Quarterly Journal of Economics, 51(2), 209-223. 
Khatser, M. V. (2014). Stratehiia rozvytku pidpryiemstva v umovakh nestabil'nosti ekonomiky derzhavy [Strategy of enterprise development in conditions of instability of the state economy]. Zbirnyk naukovykh prats' Tavrijs'koho derzhavnoho ahrotekhnolohichnoho universytetu [Proceedings of the Tavrida State Agrotechnological University], 3(27), 109-112 (in Ukr.).

Kovtun, O. I. (2008). Stratehii pidpryiemstva [Enterprise strategies]. Lviv: L'vivs'ka komertsijna akademiia (in Ukr.).

Kruhlianko, A. V. (2012). Stratehichni pidkhody do upravlinnia turystychnymy pidpryiemstvamy [Strategic approaches to the management of tourism enterprises]. Zbirnyk naukovykh prats' Cherkas'koho derzhavnoho technolohichnoho universytetu. Seriia: Ekonomichni nauky [Collection of scientific works of Cherkasy State Technological University. Series: Economic Sciences], 32(2), 63-67 (in Ukr.).

Kucherenko, V. S. (2010). Osoblyvosti ta suchasni tendentsii upravlinnia turystychnoiu sferoiu [Features and current trends in tourism management]. Naukovyj visnyk Instytutu mizhnarodnykh vidnosyn NAU. Seriia: ekonomika, pravo, politolohiia, turyzm [Scientific Bulletin of the Institute of International Relations of NAU. Series: Economics, Law, Political Science, Tourism], 1(1), 197-205 (in Ukr.).

Likert, R. (1932). A technique for the measurement of attitudes. Archives of Psychology, 22 (140), 29-35.

Malska, M. P., Antoniuk, N. V., \& Hanych, N. M. (2008). Mizhnarodnyj turyzm i sfera posluh [International tourism and services]. Kyiv: Znannia (in Ukr.).

Maslow, A. H. (1943). A theory of human motivation. Psychological Review, 50(4), 370-396, doi: 10.1037/h0054346.

Mayo, E. (1946). The Human Problems of an Industrial Civilization. Boston: Division of Research, Graduate School of Business Administration, Harvard University.

Ministry of Economic Development and Trade in Ukraine (2017). Dovidka za rezul'tatamy opratsiuvannia statystychnykh zvitiv turoperatoriv za 2017 rik [Reference for the results of the statistical evaluation of tour operators for 2017], Retrieved from http://www.me.gov.ua/Documents/ Detail?lang=uk-UA\&id=2e478d1d-8670-44cc8dd5a89c3b99f6b7\&title= GuardianSupportResultsOfficialTurperatorivZa2017-Rik (in Ukr.).

Ministry of Economic Development and Trade in Ukraine (2018). Informatsiia schodo finansovo-ekonomichnykh pokaznykiv turystychnoi sfery za I pivrichchia 2016-2018 rokiv [Information on financial and economic indicators in the tourism sector for the first half of 2016-2018], Retrieved from http://www.me.gov.ua/Documents/Detail?lang=ukUA\&id= 545f05852fa84b119f6c48aa45356631\&title=InformatsiiaSchodoFinansov oekonomichnikhPoskaznikivTuristichnoiSferiZaIPivrichchia20162018Rok okSpotSpot (in Ukr.).

Ministry of Economic Development and Trade in Ukraine (2019). Kil'kisni i iakisni indykatory iakosti pidhotovky ARV [Quantitative and qualitative quality indicators for ARV preparation], Retrieved from https://regulation. gov.ua/arv-materials/indicators (in Ukr.). 
Mintzberg, H. (1994). The Rise and Fall the Strategic Planning. New York: Simon and Schuste.

Orlova, V. M. (2015). Stratehiia innovatsijnoho rozvytku pidpryiemstva [Strategy of innovative development of the enterprise]. Ekonomichnyj nobelivs'kyj visnyk [Economic Nobel Bulletin], 1(8), 79-85 (in Ukr.).

Pearce, J., \& Robinson, R. (1991). Strategic Management: Formulation, Implementation, and Control. Homewood, IL: Irwin.

Porter, M. E. (1985). Competitive advantage: Creating and sustaining superior performance. New York: Free Press.

Schendel, D. E., \& Hatten, K. J. (1972). Business Policy or Strategic Management: A Broader View for an Emerging Discipline. Paper No. 371. Academy of Management Proceedings. Lafayette, IN: Purdue University, 99-102.

Shershnova, Z. Ye. (2004). Stratehichne upravlinnia [Strategic management]. Kyiv: KNEU (in Ukr.).

Sorokin, P. A. (2005). Sotcialnaia mobilnost [Social mobility] (M. V. Sokolova, Trans. in Engl.). Moskow: Academia (in Russ.).

Thompson, A. A., \& Strickland, A. J. (2006). Strategicheskii menedzhment: Kontceptcii $i$ situatcii dlia analiza [Strategic Management: Concepts and Cases], 12th ed. (A. R. Ganieva et al., Trans. in Engl.). Moscow: Viliams (in Russ.).

Tkachenko, T. I. (2006). Stalyj rozvytok turyzmu: Teoriia, metodolohiia, realii biznesu [Sustainable tourism development: Theory, methodology, business realities]. Kyiv: Kyiv National University of Trade and Economics (in Ukr.).

Tuchkovska, I. I., \& Yashchuk, V. I. (2017). Obgruntuvannia stratehichnykh al'ternatyv pry formuvanni konkurentnykh stratehij turystychnykh pidpryiemstv [Substantiation of strategic alternatives in the formation of competitive strategies of tourism enterprises]. Aktual'ni problemy ekonomiky $i$ torhivli v suchasnykh umovakh ievrointehratsii: Naukova konferentsiia [Actual problems of economy and trade in modern conditions of European integration: Scientific conference]. Lviv: LTEU, 220-221 (in Ukr.).

Tur, O. V. (2015). Formuvannia poniattia "stratehiia rozvytku pidpryiemstva" [Formation of the concept "enterprise development strategy"]. Intelekt $X X I$ [Intelligence $X X I$ ], 4, 38-45 (in Ukr.).

Weber, M. (1947). The Theory of Social and Economic Organizations. New York: Free Press.

Wynnycky, B., Lendel, M., Ratajczak, J., \& Sanzharovskyi, I. (2007). Vyznachennia ta vidbir indykatoriv [Definition and selection of indicators]. Posibnyk $z$ monitorynhu ta otsiniuvannia prohram rehional'noho rozvytku [Handbook on monitoring and evaluation of programs for regional development]. Kyiv: K.I.S., 25-26 (in Ukr.).

Zorin, I. V., Kaverina, G. P., \& Kvartalnov, V. A. (2001). Menedzhment turizma. Turizm kak vid deiatelnosti [Tourism management. Tourism as a type of activity]. Moscow: Finansy i statistika (in Russ.). 